\title{
Uncommon Ground: Finding Accommodation and Optimism in an Age of Political Expediency Susan Nagelsen and Charles Huckelbury
}

Prior to the circumnavigation of the globe, cartographers relied on
supposition, myth, and embellishment when configuring those lands that had not yet yielded their secrets to exploration. European maps that featured amorphous islands and continents in what would become known as the New World consistently carried the notation in those uncharted regions, "Here There Be Dragons". There were, of course, no dragons, but that did not stop either the makers or the subsequent users of those maps from believing that monsters were lying in wait for the intrepid or merely foolish who ventured to sail beyond the limits of the known world. Modern attitudes toward prisons and prisoners are analogous to those ancient misconceptions and expectations, which explains why prison abolition faces a protracted and difficult battle in the United States; after all, politicians need voters to feed the prison complex and to keep that happening prisons must remain at capacity.

\section{CONTEXT AND CONFLATION}

Nativist sentiment in the United States has always been robust, illustrated primarily by an overt hostility toward immigrants. According to British historian Tony Judt (2009, p. 86), "where immigration and visible minorities have altered the demography of a country, we typically find increased suspicion of others". The reaction includes designating English as the country's official language. There are cities in America such as Nashville and Miami and states, Oklahoma, for example, that have taken the additional step of mandating that all government business be transacted in English. This contrasts sharply with, for example, Canada's Official Languages Act of 1969, which recognized the rights of both French- and English-speaking citizens to converse in the language they prefer. ${ }^{1}$

Vigorous debates continue to erupt regarding the rights of immigrants to health care and restrictions on school attendance for their children. Those debates have spawned a form of vigilantism, in which armed patrols of citizen volunteers monitor the border between Mexico and the United States, intercepting and detaining anyone suspected of attempting to enter the country illegally. 
Given this toxic brew of xenophobia and tribalism, it follows that anyone designated as outside the cultural mainstream-including the current President of the United States ${ }^{2}$ - generates suspicion and frequent derision. Carried to the extreme, men and women whose behaviour violates the law find themselves classified as subhuman, denied fundamental rights, and declared undeserving of humanitarian consideration.

\section{A LITANY OF HORRORS}

In order to justify the mass imprisonment of its citizens, a government must convince the public of the necessity for such extreme measures and a powerful political-economic alliance in the United States has been able to realize that goal with remarkably little resistance. All that is necessary is to publicize a vicious crime, offer a tendentious inductive rationale that an isolated case of brutality indicates a general breakdown of law and order, and co-opt the electorate into supporting longer sentences and more prisons. It is this "uncertainty-elevated to the level of insecurity and collective fear" (Judt, 2009, p. 86), that is the most corrosive force threatening today's abolitionist agenda. "[A] society can give individuals a secure sense of meaning only if it gives them a secure sense of belonging to a community rooted in time [which produces] a shared understanding of what is of ultimate value, of obligations that must be met and lines that must never be crossed. Every healthy society ...needs some sort of orthodoxy" (p. 26). ${ }^{3}$ If these lines are crossed, then at least in the culture as it is presently entrenched and defined, prison is the only answer for some.

In New Hampshire, where we live, the state recently convicted Michael Addison for the murder of Manchester police officer Michael Briggs. Addison was portrayed as the quintessential urban predator, guilty of multiple prior felonies, with no redeeming social value. This contrasted sharply with Briggs' exemplary life as a dedicated policeman, husband and father. Indeed, in a supreme bit of irony, Briggs had previously saved Addison's life after Addison had been shot. The outrage following the murder persisted to the penalty phase of Addison's trial, after which the jury imposed a sentence of death. New Hampshire has not executed anyone since 1939, but Addison became the poster child for the resumption of capital punishment through the government's success in identifying him as unworthy of continued existence, not just in the community but in the world. 
More recently, four men broke into a residential New Hampshire home where a young mother and her 14-year-old daughter were sleeping. Two of the men attacked the sleeping residents with knives and a machete, killing the mother and seriously wounding the daughter before fleeing with a small amount of money and property. The sheer brutality and callous nature of the crime provoked an immediate call in the state's legislature to expand the classification of crimes for which perpetrators would be eligible for the death penalty (Schoenberg, 2010.)

Violent crimes alone, however, are not the sine qua non that drives calls for more prisons and longer sentences. Whether it was the Enron scandal or Madoff, when people feel as though they have been affronted they scream for the only thing they know: revenge. And as it stands prison is the only revenge available. Perhaps we should consider that fact.

\section{CIVIC REACTION, JUDICIAL RETRIBUTION}

During the recent global recession, men and women struggling to meet financial obligations and feed their families had little patience with apparently soulless predators who would rob them of their fortunes and their lives. Politicians consistently respond to this fear and loathing by passing even more invasive laws and increasing the punishments for existing ones. The media continue their collusion by adhering to the timehonored precept, "If it bleeds, it leads". That is, newspaper and television reporters are encouraged to give primacy to stories designed to appeal to the most prurient interests, clamoring to interview victims or survivors, with an emphasis on wringing every ounce of emotion possible from the reporting. The response is predictable.

In a recent poll by the newspaper USA Today (2009), 49 percent of the respondents thought that the death penalty in the United States was not applied enough. Another 24 percent said that it was applied adequately, while only 20 percent believed that the frequency should be reduced. Obviously, abolitionist arguments have enormous philosophical obstacles to overcome in a country in which 73 percent of the population thinks that is acceptable for the government to kill its citizens. These statistics, however, provide only a narrow window into the rebarbative theories that underlie them.

It was not until 1988, for example, that the Supreme Court of the United States barred the execution of defendants who were under the age of 16 when they committed their offences. ${ }^{4}$ The same court subsequently held 
that the Constitution does not prohibit the execution of convicted persons who were $16^{5}$ or $17^{6}$ years old at the time of the crime, as if the emotional maturity and psychological development of a tenth-grader were superior to that of a ninth grader. Adding insult to injury, the Court has also authorized executions of mentally challenged defendants ${ }^{7}$ and held that indigent death row prisoners do not have a right to counsel in state courts during appeals of their death sentences. ${ }^{8}$

Court observers should not indulge in an optimistic predictions following the more recent decision, in which the majority finally ruled that executing teenagers under 18 violated constitutional norms. That decision was also 5-4, and the four justices voting to execute high-school students remain on the Court.

\section{THE DRAGONS IDENTIFIED}

In the United States, the fear and resentment generated by crime is disproportionately directed at those defendants who do not look or sound like the majority. And that majority, shrinking as we write, ${ }^{9}$ is white. David Cole's $(2009$, p. 42) recent analysis of America's prisons describes the fallout: "[T]he biggest challenge is that the very demographics that make the pattern of crime and punishment in America so skewed against blacks and Latinos also make it all too easy for politicians, and the majorities they represent, to adhere to an unthinking tough on crime attitude".

The tradition is hardly new; the racial component of crime and punishment has a long and sordid history in America. The back story to today's startling incarceration rates includes 250 years of enslavement of black Africans and their descendants, the forcible confinement of Native American peoples to reservations, and the en masse imprisonment of Japanese Americans during the Second World War. In a grim perpetuation of the same pattern, most male prisoners in United States prisons today are poor and members of minority groups. Nearly half are African Americans ${ }^{10}{ }^{10}$ while Hispanics comprise about 18 percent of that population. ${ }^{11}$ Limited education is a contributing problem, with 49 percent of prisoners incarcerated without having earned either a high school diploma or a GED. ${ }^{12}$

For most observers, these depressing statistics, betraying as they do a systemic bias against the culturally defined Other, would beg for immediate action to redress the obvious discrimination. Sadly, even when faced with proof of the discrimination, the courts persist in pointing out those frontiers where dragons continue to lurk in order to justify capturing and killing them. 
In 1987, the U.S. Supreme Court affirmed the death sentence of an African American man convicted in Georgia of killing a white police officer during the course of a robbery. ${ }^{13}$ The defendant had submitted data to the Supreme Court supporting his assertion that defendants in Georgia charged with killing white victims were more than four times as likely to receive a death sentence than those convicted of killing a nonwhite victim. In another 5-4 opinion, the Court concluded that although the study indicated "a discrepancy that appears to correlate with race", the evidence did not require overturning the sentence of death. It should therefore surprise no one that Michael Addison, sentenced to death in the New Hampshire case previously discussed, is black while his victim was white. It is interesting to note that New Hampshire had gone decades without having a capital case and then found itself with two cases running simultaneously - one with a black defendant (Michael Addison) and one with a white defendant (John Brooks). It is also interesting to note that the white defendant was sentenced to life without parole. As Gary Younge (2008, p. 10) put it in a recent essay, "Never having considered solidarity with blacks and Latinos, [white Americans] see them not as potential allies but as perpetual enemies".

\section{ECONOMIC DISENFRANCHISEMENT}

Aggravating the racial component driving mass incarceration is the pronounced economic disparity between those going to prison and those who are not. Following a marked decline through the 1960s, the chasm between rich and poor, irrespective of the metric used, has increased significantly. "In the US today, the Gini coefficient ${ }^{14}$ - a measure of the distance separating rich and poor-is comparable to that of China" (Judt, 2009 , p. 87). Although one's civic status should not be a function of his or her economic participation, that is precisely the nature of American society today, where the poor, from whose ranks most prisoners are drawn, remain largely voiceless with respect to elected officials who pass the laws that disproportionately affect them.

The resulting dichotomy has created a cult of celebrity worship and corporate greed that need not be revisited here but that has produced a culture in which a balance sheet, athletic ability, or star power determines an individual's worth as a human being. Ironically, it was Adam Smith, the titular father of the free market, who observed that this "disposition to admire, and almost to worship, the rich and powerful, and to despise, or, at 
least, to neglect persons of poor and mean condition [...] is [...] the great and most universal cause of the corruption of our moral sentiments" (ibid).

With respect to the current state of those moral sentiments, the disturbing ease with which prisoners are written out of the civic process is no less brutal than the ancient Greek punishment of banishment from the polis. Those deemed morally reprehensible by the majority forfeit any consideration, banished as they are to facilities that the majority justifies by filling them with those it despises. Absent is any sense of collective moral outrage over such asymmetrical treatment. David Cole (2009, p. 43) reminds us, "our addiction to punishment should be troubling not only because it is costly and often counterproductive, but because its race and class disparities are morally unacceptable". Indeed, it should be troubling, but it is not.

Such an egoistic philosophy threatens the fabric of society for a number of reasons, most prominently the lack of a social cohesiveness that binds citizens together and promotes mutual recognition as human beings. Where there is no society, there is only competition and scant regard for underperforming men and women on the margins, similar to the brutish world envisioned by Thomas Hobbes in his Leviathan (1651). We need look no further than the former British Prime Minister Margaret Thatcher for corroboration of this kind of social evisceration: "There is no such thing as society. There are only individual men and women and families" (Judt, 2009, p. 92).

The obstacle to abolition thus lies in both the policies of the state and the language used to justify them. To be successful, we must therefore address both.

\section{STRATEGIC ENGAGEMENT}

Concomitant with the intrinsic hostility toward criminal defendants is the misperception that "abolition" means a modern storming of the Bastille by contemporary sans-culottes and setting loose the monsters inside to prey on innocent children and unsuspecting adults. Educating the public about precisely who is in prison and why must be our priority and should include expanding the public's awareness of the benefits, both moral and economic, of abolition. This will naturally involve organizing like-minded groups that currently work at cross purposes, both locally and transnationally.

In a recent essay in the $J P P$, Kenneth Hartman (2009) provides what is perhaps the clearest example of this challenge. While many groups currently 
work for elimination of the death penalty, they feel compelled to advocate for a sentence of life without parole to replace death as a punishment, simply because the public demands a harsh alternative. According to Hartman, the California prison system already holds 3864 prisoners serving life without parole (p. 35). How, then, does one argue for the abolition of prisons when sympathetic organizations are advocating their persistent existence as placeholders to stop the government from killing people?

We do not quarrel with the ultimate intent - deconstruction of the current system - of those organizations. We suggest that when exploring abolitionist strategies, modifying current models can be a helpful beginning. Here, Julia Sudbury's (2009) discussion of her group's approaches in California provides a lucid example of what can be done - and what might yet be done.

Sudbury was among those who founded Critical Resistance 10 years ago at Berkeley, "a turning point in abolitionist work in the United States" (Sudbury, 2009, p. 177). And yet, although we have been active in many prison reform activities for over two decades, neither of us had ever heard of CR until Sudbury's essay appeared in the Journal of Prisoners on Prisons. Whether this is due to CR's absence of national publicity or our lack of awareness, the result is the same: isolated struggles in geographical pockets where unity should be employed. This confirms Judt's (2009) observations regarding the difficulty in organizing and sustaining shared purposes in a country as large as the United States. As Judt puts it, social democracies function best in "small, homogeneous countries, where issues of mistrust and mutual suspicion do not arise so acutely" (p. 86).

Sudbury (2009, p. 177) describes her preliminary work in "[exploring] the ways in which prisons had become embedded in the political and economic landscape". This is, of course, mandatory if we are to understand fully the nature of the adversary and the consensual silence supporting mass incarceration in order to develop coherent responses. Without, however, an orchestrated educational program, designed to explain abolition to a sceptical public, the results will always be the gloomy reality Sudbury describes: "Despite our best efforts, the use of imprisonment as a catch-all solution to social problems - from poverty to addiction - has become more, not less [e]ntrenched" (ibid).

To counter and potentially reverse this trend, we should, as noted, first undertake a rigorous examination and explanation of the nature of prison abolition in order to assuage public fears. The corollary is a concession - to the sceptics and ourselves - that modern prisons hold some individuals who 
must be physically restrained, in some cases for the duration of their lives. A noteworthy example of this tactic is President Obama's intent to close the military prison at Guantanamo Bay.

During his campaign, the President cited examples of men who had been swept up in the incarceration frenzy of the two-front war in Iraq and Afghanistan, only to be subsequently cleared of any offence that warranted imprisonment, including minor association with questionable organizations. That number as we write in June 2010 has reached 560 (NPR, 2009). The Government's recent decision to close the prison and transfer 100 of the remaining 198 prisoners to a maximum-security prison in Illinois carries with it the implicit assumption that some of the prisoners cannot be freed. Although the move marks a watershed moment, it has been met with vigorous opposition (ibid)

Representative Mike Pence (R-IL) invoked the tired canard that moving the prisoners and closing Guantanamo will put the public at risk. Senator Roland Burris (D-IL) countered that he had full confidence in the safety and security of the new facility, a sentiment echoed by Senator Dick Durbin (D-IL), who added: "We believe this is in service of our country" (Jackson, 2009). While the closing the prison at Guantanamo represents a step forward, positions on both sides of the argument, as illustrated by these antagonistic reactions, present severe obstacles for abolitionist campaigns.

The two senators' support of reducing the number of prisoners and transferring them to Illinois includes an economic determinant, as opposed to any humanitarian consideration. The move will bring an estimated 3000 jobs and "valuable federal dollars" to the area (Jackson, 2009). Officials from other jurisdictions that were competing for the Guantanamo prisoners said they would welcome the jobs created by the transfer (ibid). As long as opponents of abolition continue to frame the argument in terms of public safety and fiscal necessity, promising steps toward the abolitionist goal, such as reducing both the number of prisons and prisoners inside them, will not bring the desired changes without first demonstrating that the number of prisons can be radically reduced without endangering anyone's personal or financial welfare.

\section{THE NUDGE FACTOR?}

As elementary as it might sound, the first step toward abolition of the monolithic prison system now thriving in the West is a precise definition 
of the society we want. This might begin with a "moral narrative in which to situate our collective choices", thereby providing a "substitute for the narrowly economic terms that constrain our present conversations" (Judt, 2009, p. 94). Following that definition, we suggest posing specific questions in order to find common ground with our opponents: What are the structural and philosophical defects in the policies that support mass incarceration? What can we do about them? What have we lost as a result of implementing those policies? As Judt (2009) eloquently argues, the answers to such questions should take the form of a moral critique, but we cannot ignore the power relationships and economic factors that continue to play such dramatic roles.

Our task is therefore to explain to a skeptical public why America's prisons and the policies that support them offend our sense of justice and equality and concomitantly diminish access to social services that would otherwise be available to the general public. Part of that explanation must be a recognition of the many existential factors - war, terror, pandemics, recession, climate change - that have made us "less confident of our collective purposes, our environmental well-being, or our personal safety than at any time since World War II" (Judt, 2009, p. 96).

One promising avenue for addressing this skepticism is an approach derived from behavioral economics and experiments on how people process information, particularly numerical data. Given the often illogical and counterproductive nature of contemporary prison systems, it will surprise no one that the work of Amos Tversky and Daniel Kahneman (1973) "challenged the prevailing notion that the economic decisions [people] make are rational" (Groopman, 2010, p. 12). Specifically, people are "prone to incorrectly weigh initial irrelevant information into [their] analysis" (ibid). This, of course, describes the reaction of Western democracies to perceived internal criminal threats, and explains the proliferation and industrialization of prisons.

An excellent beginning to remedy these misperceptions would be a systematic description of precisely who is inside all those prisons. The number of state prisoners held for drug offenses has increased thirteen fold since 1980, and the half of the prisoners held in federal prisons are being held on drug-related offenses. ${ }^{15}$ Contrary to popular belief, prisons are not full of drug kingpins, who own fleets of cars and airplanes and who vacation on Saint Tropez. Prisoners tend to be lower echelon addicts 
who would clearly benefit from therapeutic intervention. Instead, they are sent to prison, often with life sentences, when they could be treated more economically and effectively in a community based setting without endangering anyone.

Convincing a predisposed public to reconfigure its standard response to criminalized behavior, however, will be no easy task. As Groopman (2010) points out, maximum-security prisons have acquired a default status that will require genuine innovation to modify, because most people continue to choose the default option, building and maintaining more prisons, instead of making an effort to identify alternatives. As Sunstein and Thaler (2008) put it, "These behavioral tendencies toward doing nothing will be reinforced if the default option comes with some implicit or explicit suggestion that it represents the normal or even the recommended course of action". How, then, to combat such an entrenched and implacable adversary? By "nudging" them toward change.

Abolitionists can, utilizing Judt's moral narrative model, begin to exert a subtle influence on social philosophy that shifts the paradigm away from the perceived normality of massive incarceration and its associated costs. Our task is to offer viable alternatives that will enable people to feel that those new choices result in improved personal feelings, as judged by those making the choices. Diverting nonviolent drug offenders is a logical first step and one the community will find more palatable especially when the offenders are their husbands, sons and daughters. It is an infinitely more appetizing than the idea of freeing a dangerous predator.

Acknowledging those unreconstructed predators does not abdicate the battle for abolition. On the contrary, it infuses a sense of recognition and kinship that will aid in the incremental process that must lie at the heart of all abolitionist efforts. We are, pace Ms. Thatcher, a society after all. Dangerous individuals do indeed exist in our world, and our failure to identify them and the need for facilities to secure them jeopardizes any chance of progress, at least in the United States, which has become the model for applied criminal justice in the Western world.

Only after conceding this point can we begin the graduated process toward elimination of the physical plants and their philosophical underpinnings that have corrupted our response to criminalized behaviours. And it must be a graduated, Darwinian process. Abolition will not come easily or quickly for most have been fed a diet of fear. Rather, it will be a death of attrition, as 
the current prison-industrial complex becomes too cumbersome to support and begins to starve, coupled with a new public awareness of the cost, both in financial and human terms, of maintaining it. No one disputes that we have a fight ahead of us, but neither does anyone deny the effort is worth it.

\section{ENDNOTES}

$1 \quad$ See $<$ http://www.parl.gc.ca/information/library/PRBpubs/prb019-e.htm>.

2 So-called "birthers" continue to insist that President Obama was born in Kenya and therefore constitutionally barred from holding the office. Conservative pundit Glenn Beck has accused the President of hating white people.

3 This was taken from "The Story of the Woman's Party”, accessed at <http://www. archive.org/stream/storywomanspart00gillgoog/storywomanspart00gillgoog_djvu. txt>.

4 Thompson v. Oklahoma, 108 S.Ct. 2687 (1988).

5 Wilkins v. Missouri (subsumed within Stanford below).

6 Stanford v. Kentucky, 109 S.Ct. 2969 (1989).

7 Penry v. Lynaugh, 109 S.Ct. 2934 (1989).

8 Murray v. Giarratano, 109 S.Ct. 2765 (1989).

9 Current analysis indicates that white Americans will be a minority by 2045 (see Younge, 2009, p. 10).

10 The actual percentage of blacks is 43.7 percent of blacks nationwide are incarcerated. See $<$ http://www.scribd.com/doc/938139/Percentage-of-Blacks-Inca rcerated-vs-Population $>$.

11 See $<$ http://abcnews.go.com/TheLaw/story?id=5009270>.

12 See $<$ http://nces.ed.gov/pubs94/94102.pdf $>$.

13 McCleskey v. Kemp, 107 S.Ct. 1756 (1987).

14 Judt cites "High Gini is Loosed Upon Asia" in The Economist, 11 August 2009.

15 See $<$ http://www.sentencingproject.org/template/page.cfm?id=128>.

\section{REFERENCES}

Cole, David (2009) “Can Our Shameful Prisons Be Reformed?", The New York Review of Books, pp. 41-43 - November 19.

Groopman, Jerome (2010) "Health Care: Who Knows Best?", The New York Review of Books, pp.12-16 - February 11.

Hartman, Kenneth (2009) “The Other Death Penalty", Journal of Prisoners on Prisons, 18(1\&2): 35-38.

Hobbes, Thomas (1651) Leviathan, n.p. n.d.

Jackson, Henry C. (2009) "Prison to get Gitmo detainees", The Concord (NH) Monitor - December 16.

Judt, Tony (2009) "What Is Living and What Is Dead in Social Democracy?", The New York Review of Books, pp. 86-96 - December 17. 
National Public Radio (2009) "News summary at 8:00 p.m." - December 20.

Riley, Richard, Secretary (1994) "Literacy Behind Prison Walls", National Center for

Educational Statistics. Retrieved from <http://nces.ed.gov/pubs94/94102.pdf>.

Schoenberg, Shira (2010) "Death penalty expansion too late for House liking", The Concord (NH) Monitor - January 7, 2010.

Sudbury, Julia (2009) "Building a Movement to Abolish Prisons: Lessons from the U.S.", Journal of Prisoners on Prisons, 18(1\&2): 177-184.

Sunstein, Cass and Richard Thaler (2008) Nudge: Improving Decisions About Health, Wealth, and Happiness, Yale University Press.

USA Today (2009) "Al" - December 2.

Younge, Gary (2009) "Obama and the Decline of White America”, The Nation, p. $10-$ October 26.

\section{ABOUT THE AUTHORS}

Susan Nagelsen is Director of the Writing Program at New England College in Henniker, New Hampshire, where she has taught for over 25 years. She is an essayist and a fiction writer as well as the author of two writing manuals. She teaches first-year courses, as well as advanced essay writing courses such as the art of the essay and content based writing. She also teaches in the Criminal Justice program where her course focuses on teaching students about prison from the point of view of prisoners. Her most recent published fiction can be found in the fall 2005 edition of the Henniker Review, Tacenda, Bleakhouse Review and in the Journal of Prisoners on Prison Volume 14(2), an issue addressing aging in prison. She is a frequent contributor to the $J P P$ and is currently Associate Editor. She is also the editor of an anthology of work by incarcerated writers entitled Exiled Voices, Portals of Discovery (New England College Press, 2008). The book features 13 incarcerated writers with an introduction to each written by Nagelsen and is being used as a textbook in courses focusing on criminal justice issues.

Charles Huckelbury was sentenced to life imprisonment-35-year minimum - at the age of 27 and spent three decades in prison. Awarded second place in Prison Life's fiction contest in 1995, he won the PEN American Center first prize for fiction in 2001. A regular contributor to the JPP since 1997, Charles joined the Editorial Board in 2001 and is now an Associate Editor. He was one of four featured writers in Shawn Thompson's Letters From Prison (Harper Collins, 2001). His new book of poetry, Tales From the Purple Penguin (BleakHouse Publishers, 2008) has received rave reviews from students and academics. 